Bősz ANETT ${ }^{1}$

\title{
A FENNTARTHATósÁg ÉS AZ ÚJ GENERÁCIÓ SZEMLÉLETE \\ SUSTAINABLE DEVELOPMENT AND \\ THE APPROACH OF THE NEW GENERATION
}

„Céljaink nem változnak: béke, haladás, társadalmi igazságosság és egy fenntartható jövő. Azonban az eszközöket, amelyeket e célok elérésére használunk, az új korszak kihívásaihoz kell igazítanunk.” Kofi A. Annan, ENSZ fötitkár: „Mi, a Népek” Az ENSZ szerepe a XXI. században [In: Simai, 2016]

Az egyetem és az iskola többek között azért fontos intézmény, mert hidat képez generációk között, és nemcsak a tudományt, hanem azokat az értékeket is továbbadja, melyeket korábbi nemzedékek halmoztak fel. Sokat jelentett számomra, hogy együtt dolgozhattam Simai tanár úrral, a „Nemzetközi makrogazdaságpolitika” címü tárgy keretében. Ugyan szemináriumvezetöként - szándékom ellenére - kevésszer jutottam el az általa tartott elöadásokra, a tárgy kötelezö irodalmául szolgáló könyv sokat adott és tanított nekem. Jelen írás a IV. ipari forradalom és a XXI. század egyéb kihívásaira adott válaszaiból készült egyik könyvének - A harmadik évezred nyitánya - egy lehetséges olvasatát, valamint egy tanulmány összefoglalóját tartalmazza, amivel szeretném megmutatni, menynyire fontos, hogy ne pusztán a Föld környezeti értelemben vett fenntarthatósága, de a társadalmi értelemben vett fenntarthatóság is fontossá váljon számunkra az új világrendben. Ehhez, meglátásom szerint, minden iskolában szükség van „Dumbledore”-ra, aki vigyázó szemét nemcsak a tudományra, hanem az erkölcsre is veti. És persze, azokra a hallgatókra, „Harry”-kre, „Ron”-okra és „Hermione”-kra, akik az igazságosság védöernyője alatt nemcsak az iskolában, de a világban is a jót keresik. Ezt bizonyítja egy közelmúltban megjelent tanulmány, „The greatest magic of Harry Potter: Reducing prejudice" (Harry Potter 2legnagyobb varázslata: csökkenti az elöítéleteket) címmel. E dolgozatban azt kívánom bizonyítani, hogy a nagy intézményrendszerek mellett az értékrend és az értékrend sikeres átadásának képessége is szükséges a XXI. századi kihívásokra adott válaszok megtalálásához.

\footnotetext{
${ }^{1}$ doktorandusz, Budapesti Corvinus Egyetem

${ }^{2}$ A Harry Potter történetek egy párhuzamos, varázslók és boszorkányokból álló világról, valamint a benne müködő iskoláról szólnak.
}

DOI: 10.14267/RETP2020.01.11 
Schools and universities are important, first, because they bind generations together. The education system hands on science and values that have been cumulated by decades and centuries. It means a lot to me that I had the opportunity to work together with Professor Mihály Simai as a seminar leader on the subject of International Macro Economic Policy. Although - despite my intents - I did not have enough capacity to visit the lectures of the Professor, the book - A harmadik évezred nyitánya (The Future of the Global Governance) - that was given as required reading for our students impressed me and thought me a lot. This paper contains a possible interpretation of the book and summarizes a study. The aim of this study is to present that in the new world order, sustainable development in our social relationships and peacekeeping has such a high level of importance as sustainable development in the environment and ecosystem. Therefore - I believe - we need "Dumbledore" in every school who keeps guard not just on science but also on morality. Moreover, of course we need those students, 'Harries, Rons and Hermiones' who are looking for the good at schools and in the world, under the shielding of justice. A study was published recently with the title of 'The greatest magic of Harry Potter: Reducing prejudice'. In this paper, I would like to prove that besides finding a way to transform and develop our great institutions, the capability of handing over values is also highly needed for finding answers for the challenges of the 21st century.

\section{BEVEZETÉs: EgY GENERÁció MORALITÁsÁNAK MEgALAPOZÁSA?}

Új tevékenységi, fogyasztási, alkotási modellek keresése zajlik. A környezetvédelmi értelemben vett fenntarthatóságért való felelősségvállalás nagyobb arányban jelenik meg, új életmód alakul ki. Törekvések vannak arra, hogy megálljon a túlfogyasztás és a túlzott hulladékképzés. Az újabb generációk erre nyitottabbnak mutatkoznak.

Ma a tolerancia-eszme számos társadalmi csoportban megkérdőjeleződik a szabad világban, mert hiányzik az az erkölcsi alap, amit mindenki magáénak tud. Azért kell a négy alaperényről beszélnünk, mert így van igazodási pontunk, amely a tolerancia-eszmén túlmutat. Ezek rámutatnak arra, hogyan tegyünk különbséget jó és rossz között és hogyan álljunk ellen a kettő közti határok elmosásának.

Új generáció nőtt fel az elmúlt három évtizedben, amely kamaszkorától kezdve nagy számban olvasta a Harry Potter könyveket. Ez a nemzedék már gyerekkorában, szerethető gyerekek képében találkozott az ókori görög filozófia alaperényeivel egy olyan évszázad végén, amelyben két világháború is megmutatta, mit okoz egy társadalomban a hiányuk. A bátorságot Harry Potter, a bölcsességet Hermione Granger, a mértékletességet Ron Weasley jeleníti meg. A fiatal olvasó azzal is szembesülhetett, hogy e három fölött ott áll az igazságosság, Albus Dumbledore személyében. Négyen alkotnak egységet: kizárólag értékek szövetségében érhetik el céljaikat, így vethetnek véget a Voldemort-jelenségnek, aki a Harry Potter regényekben a gonosz szerepét játssza.

A tolerancia-eszmének nincs válasza arra, hogyan rekesszük ki Voldemortot - nem müködik az önfenntartáshoz nélkülözhetetlen társadalmi immunrendszer. A négy alaperény müködésbe hozhatja. 


\section{VEZETÉS, ERKöLCS, TUDOMÁNY}

A vizsgálódás, amit a tanulmányban látunk, nem új keletű. Már az ókori Görögországban foglalkoztak a drámával és annak az emberekre gyakorolt hatásával, a szimpátia kialakulásával: a néző „a szereplők cselekedeteivel - nem pedig elbeszélés útján - a részvét és a félelem felkeltése által éri el az ilyenfajta szenvedélyektöl való megszabadulást" [Arisztotelész, 1992:13, 49b]. Mindhárom tanulható, erkölcs nélkül nincs vezetés, de nincs tudomány sem. Nagy probléma például, hogy az elmúlt évtizedek társadalomszervezési ajánlatát megfogalmazók sora „nem tudott arról, hogy az állam müködésének nem csak jogi, de bölcseleti törvényei is vannak". [Gervai-Trautmann, 2013] A felvilágosodás az erkölcs sokoldalú vizsgálatát is elhozta. „Ha tehát elöfeltételezzük az akarat szabadságát, akkor már fogalma puszta felbontásából következik az erkölcsiség és annak elve." [Kant, ford. Berényi, 1991:82] Kant szerint az erkölcsösség elérhetö, ha minden embert felruházunk a szabadsággal. John Locke az iskolát nevezte meg elsődleges intézményként, Adam Smith látja: megvan bennünk az empátiára való képesség, mert bele tudunk helyezkedni a másik ember helyzetébe, és bár a mi érzelmünk nem lesz olyan erős, mint a másik ember eredeti érzelme, mégis - ahogyan Smith fogalmaz - „ez a két érzés evidensen összecseng annyira egymással, ami elegendő a társadalom harmóniájához" [Smith, 1982:22].

Smith megnevez egy intézményt, amely értéket képvisel és ad át az embereknek: a kereskedelmet. Elgondolása szerint a piac egyúttal morális cél is, hiszen a kereskedőtársadalom polgárokból áll, akik igazodási pontokhoz harmonizálták a saját életüket, így hatékonyabbá és jobbá váltak. Vizsgálta, hogy hogyan lehetséges, hogy önérdekkövetö emberek sokaságából jól működő, koherens gazdasági folyamatok származtak. A piacon, az alábbiak szerint látja harmonizálhatónak az egyéni érdekeket: „Ebédünket nem a mészáros, a sörfőző vagy a pék jóakaratától várjuk, hanem attól, hogy ezek a saját érdekeiket tartják szem elött. Nem emberiességükhöz, hanem önszeretetükhöz fordulunk, és sohasem a magunk szükségéröl, hanem a rájuk váró elönyökröl beszélünk nekik." [Smith, 1959: 64] „A könyv időtálló tanácsokat ad arra vonatkozóan, miként bánjunk a pénzzel, a vágyainkkal, a hírnév és az erkölcs kérdéseivel. Elmondja az olvasónak, hogyan lelhet a boldogságra, hogyan kezelje az anyagi sikereket és bukásokat. Felvázolja, miként lehetünk erényesek, jók, és miért éri meg számunkra, hogy azok legyünk." [Russ, 2014: 4]

Az erkölcs és a morál vizsgálatának évezredes története a XX. században is folytatódott. A közgazdaság-tudomány művelöi közt éppúgy megtaláljuk őket, mint a filozófusok közt. Wilhelm Röpke a II. világháború borzalmai után nem kevesebbre, mint a társadalom „meggyógyítására” vállalkozott, és úgy látta: „Az pedig, hogy a gazdaságpolitikát igazitsuk az emberhez és ne megfordítva, egyenesen erkölcsi és emberiességböl következö parancs." [Röpke in J. Horváth, 2000: 18]. A jóra nevelés iskolai és államigazgatási feladat is. Ezt nyújtja a Roxfort, s egyúttal a lehetőséget, hogy a jövő varázslógenerációi Thomas Hobbes állama helyett John Locke államában találják magukat, azonban ehhez nekik is tenniük kell.

\section{Az Állam és Az ISKola viszonya}

A Roxfort Boszorkány- és Varázslóképző Szakiskola nem pusztán egy oktatási intézmény. A varázslóvilág jövő nemzedékeinek akadémiája, itt dől el, ki lesz egyáltalán a varázslók „utánpótlása”. Az iskola szerepe az államigazgatás keretein belül a társadalomszervezési ajánlat értékrendjének és a mindennapi életben használatos tudás átadásában fogható meg. Ezek közül az értékrend hosszú távú stabilitása a mindenkor fennálló állami intézményrendszert is ellenőrzi, 
ugyanakkor az intézményrendszer feladata az értékrend feletti őrködés is. Az értékrend így eszköz és cél is egyúttal.

$\mathrm{Az}$ iskolának különleges felelőssége és szerepe van az államigazgatásban, az állam felelössége pedig kettős az iskolával szemben. Egyfelől biztosítani kell az iskola müködésének jogi és intézményi feltételeit, másfelől biztosítania kell az iskolapolgárok és az intézmény szabadságát. Összetett feladat, az intézmények stabilitásán és a stabil intézményrendszeri keretben kialakítható kölcsönös bizalom szükséges ehhez. Az iskola az értékrenden túl a demokratikus kultúrát, a használható tudást, valamint az egymás iránti tisztelet kultúráját is átadja. Hierarchiája - természetéből fakadóan - nem elhagyható.

\section{A VOLDEMORT-JELENSÉG ÉS AZ INTÉZMÉNYRENDSZER STABILITÁSÁ- NAK FONTOSSÁGA}

Voldemort a varázslóvilág kegyetlen tömeggyilkosa. Szándéka megszerezni a hatalmat a boszorkányok és varázslók fölött, eszközökben azonban nem válogat, és nagy számban állítja maga mellé azokat, akik nem tudnak vele szembeszállni. Voldemort az értékrend hiányát jelképezi. A „sötét nagyúr" megerősödése ugyanakkor az erőszak-monopólium és az iskola kudarca is. A társadalom fennálló rendjét és a békét megdönteni igyekvő egykori diák a rendszer hibája is. A mágiaügyi minisztériumban hirtelen köpönyeget fordítók megzavarhatják a társadalmat a jó és a rossz elválasztása tekintetében, holott a mindenkori vezetés történelmi felelössége morális mércével mérni cselekedeteit, és a kettő közti világos különbségtétel képességének kifejlesztésére ösztönözni. Amennyiben ez nem történik meg, a tág értelemben vett állam nem szolgálja a társadalmat, helyette - kiszámíthatatlan játékszabályok mellett - despotizmus alakul ki. Az igazságszolgáltatás hatalomtechnikai eszközként való használata nem fér meg a demokratikus intézményrendszer keretei között. „A három hatalmi ág egy kézben való összpontosulása a zsarnokság." [Tóth, 2016:26]

A Roxfortban megkezdődő diktatúrakiépítés annak következménye, hogy a varázslóvilágban megbomlott a négyes egység, a hatalmat és a társadalom szervezését nem az alaperényekből vezetik le. A történetben zajló folyamatok azt jelentik, hogy a bátorságnak, a bölcsességnek és a mértékletességnek az igazságosság elvesztése mellett is képessé kell válnia arra, hogy helyreállítsa a rendet és a társadalmi békét.

\section{A TOLERANCIA-ESZME ELLENFELEI ÉS AZ Ő IGAZSÁGUK}

Piton és Harry Potter viszonyában a józan ész, a fontolva haladók és a tolerancia-eszmében magukat már megégetők keserủ szájíze csap össze a forradalmi hévvel és a fejlesztésre szoruló tudás mellett is jól használt tehetséggel, ami olykor önveszélyes is lehet. Piton tágabb értelemben a jogállami normák és az egyenlő bánásmód melletti kiállás legszigorúbb őre.

A Harry Potter történetek másik nagy értékelemző részlete a barátság értelmezése. A regényekben megjelenő tanárok is azt jelenítik meg, hogy az erényt szeretjük a másikban. Azt szeretjük benne, amiben a legjobb. Politikai intézményrendszer van a Harry Potterben, és ez arról szól, hogy a közösség egy formája a barátság. Ennek a vizsgálódásnak is nagy hagyománya van. David Hume nem pusztán az erénnyel, a barátsággal is foglalkozik, azt mondja: „Elismerem, hogy a dolgok jelenlegi rendjében az erénnyel nagyobb lelki nyugalom jár együtt, mint a bünnel, s a világ részéröl az erény kedvezöbb fogadtatásban részesül. S azzal is tisztában vagyok, hogy az emberiség 
múltbeli tapasztalatai szerint a barátság az emberi élet legnagyobb öröme, s a mértékletesség a nyugalom és boldogság egyedüli forrása. Az erényes és vétkes életmód közt sosem ingadozom, mert tudván tudom, hogy a jó szándékú emberek számára minden elöny az elöbbi oldalán van." [Hume, $1748]^{3}$

\section{Az ÉRTÉKREND ALKALMAZÁSA}

Az állam létrehozhat bármilyen intézményt, az értékrend helyes alkalmazása a kérdés, akármilyen erkölcsi szabályt tekintünk is. Amennyiben kikényszerítésről beszélünk, már messze járunk az „értékrend” fogalmától. Nem véletlen, hogy számos kultúrában előkerül a szeretet kérdése: akár a vallást, akár a felvilágosodás korában gondolkodó filozófusok iskolaalkotását nézzük, ezzel találjuk szembe magunkat. A szeretet képes az értékrend alkalmazására. Harryt az édesanyja a szeretetével mentette meg, ezt is egészen fiatalon tanulták meg az első Harry Potter olvasók. A szeretet társadalmi szinten a másik ember méltóságának mindenekfölött való tiszteletében testesül meg, még akkor is, ha klasszikus értelemben véve nem „szeretjük” a másik embert, aki társunk a társadalomban. Egyéni szinten a szeretet, társadalmi szinten a másik ember tisztelete az, amely képes az értékrend alkalmazására.

Minden nagy intézményrendszer felépítésére igaz ez. Az államigazgatásra éppen úgy, ahogyan a piacgazdaságra. A jogállam alapja a morál. Ezt már az a Ludwig Erhardt írta le, aki gazdaságpolitikusként kereste arra a lehetőséget, hogy a III. Birodalom rémtettei után egy olyan társadalmat tudjanak felépíteni Németországban, amely az emberi méltóság mindenekfölött való mivoltán és ennek mindenki által való elfogadásán nyugszik. Csak morálisan erős társadalomszervezö képes olyan törvényeket alkotni, amelyek kikényszerítik az erkölcsös viselkedést a szereplőkből. „Nem a verseny az, ami megöli a versenyt, hanem sokkal inkább az állam, a morálisan gyenge állam az, ami, miután elhanyagolja a piaci rend biztositásával kapcsolatos kötelezettségeit, hagyja eltorzulni a versenyt, majd hagyja, hogy fosztogató hajlamú lovagok visszaélhessenek jogaikkal és megadják a kegyelemdöfést az eltorzult versenynek" [DardotLaval, 2013:175]

A tanulmány [Vezzali et al., 2015] kérdőíves módszerrel dolgozik, három korcsoportot vizsgál. Az előfeltevés, mely szerint a Harry Potter csökkenti az előítéleteket, igaznak bizonyult. A dolgozat állítása az, hogy azok, akik olvasták a Harry Pottert, kevésbé előitéletesek, és szolidárisabbak a hagyományosan kirekesztett társadalmi csoportokkal szemben. A könyv felveti a származás alapú megkülönböztetéstől való távolmaradást (Hermionét mugli származása miatt Malfoy csúfolja, azonban a többiek a védelmére kelnek). Ron Weasley nagyon szegény családból származik, Neville Longbottom ügyetlen és esetlen, Hagrid kilóg a sorból, nem pusztán óriás termetével, de azzal is, hogy ugyan a Roxfortban tanít, de nem varázsolhat. Harry Potter maga is kisebbségi létbe kényszerül azzal, hogy elveszítette a szüleit és kirekesztő gondolkodású nevelöszülőkhöz került, nem élvez a család többi tagjával azonos jogokat.

A könyvek szereplői nem pusztán elfogadják egymást, de mind készek segíteni egymáson. A tanulmány szerzői lényegében azt állítják, hogy a Harry Potter könyvsorozat úgy szocializál, mintha a Roxfortban közvetített értékeket tanulták volna meg, mintha maguk is a boszorkány- és

\footnotetext{
${ }^{3}$ https://www.scribd.com/document/237239070/Hume-Tanulmany-Az-Emberi-Ertelemr\%C5\%911
} 
varázslóképző szakiskolába jártak volna. A különbség azonban az, hogy a kutatásban részt vevők toleranciaszintjének emelkedése nem varázslat volt, hanem tudomány.

A társadalomszervezés egyik legfontosabb intézménye az iskola. Mivel a vezetés, az erkölcs és a tudomány kéz a kézben járása elengedhetetlen egy sikeres társadalom kiépítéséhez, olyan iskolára van szükség, ahol mindhárom egyszerre van jelen. A tolerancia-eszme a globális kihívások és társadalmi válságok miatti megkérdőjeleződése veszélyt jelent a társadalom egészére. A tolerancia-eszme lényegéből eredő saját korlát, hogy a társadalom rombolására tett kísérletek nem kirekeszthetők. Olyan megoldást keresése indokolt, amellyel kiszürhető, hogy egy értékrend nélküli erő kerekedjen felül egy közösség életében.

\section{MIÉRT FONTOS EZ, ÉS HOGYAN KAPCSOLÓDIK A HARMADIK ÉVEZRED NYITÁNYA CÍMÜ KÖNYVHÖZ?}

Minden, amitől eltávolodott az emberiség - az ókori görög filozófia által meghatározott alapértékek, a társadalmi béke és az egymás iránti tisztelet kultúrája - szükséges a XXI. század kihívásainak leküzdéséhez. Simai Mihály könyve az emberiség jövőjének lehetőségeit elemzi, felsorolja a jelenkor emberét és ökoszisztémáját érö összes kihívást, számos adattal alátámasztva azok súlyosságát. Szól a kihívások lehetséges megoldásairól, ökológiai, mikro- mezo- és makroökonómiai szempontból, felveti e problémák egy másik vetületét is: nem pusztán a természet, de a társadalom is súlyos veszélybe került.

E dolgozat amellett érvel, hogy ahogyan a természetnek, úgy a társadalomnak is léteznek alaptörvényei. Amennyiben utóbbiakat az alaperényekből vezetjük le, esély nyílhat a társadalomszervezés új minőségére. Ez pedig a segítheti az emberiséget a jelenkor kihívásaira adott válaszkeresésben.

\section{A XXI. SZÁZAD VILÁGA A KOMPLEX, GLOBÁLIS TRANSZFORMÁCIÓK VILÁGÁBAN}

A könyv definíciót ad a társadalmi rend fogalmára, miszerint: „stabil, kiszámítható és békés társadalmi vagy nemzetközi viszonyok, amelyek fenntartják a biztonságot és biztositják a közérdek érvényesülését" [Simai, 2016:22.]. A közérdeket szolgáló társadalomszervezési ajánlat megtalálásához nem elég a globális kormányzás újabb korszellemhez igazodó intézményeit jól szervezni, szükség van a békés társadalmi és nemzetközi viszonyok létrejöttére is. Ez az alaperények megfelelő közvetítésével elérhetö. A tanulmány és a könyv együttes elemzésére ez a magyarázat. A Simai Mihály által megírt világrend egy „olyan társadalmi konstrukció, amelynek jellege döntő mértékben függ a nemzetközi rendszerben meghatározó hatalmi érdek-és értékviszonyoktól”. [Simai, 2016:23] Mivel ma a világrend is „mélyreható átalakulás állapotában van”, a mintegy 70 éve kialakított régi világrend felbomlásának következménye valamifajta „világrendetlenség”, amely globális méretekben a háborúkat, a tömegmészárlásokat, éhínséget, terrorizmust, és az emberi jogok nagymértékü sérülését hozza magával. A világrend alapvetően katonai szövetségi rendszeren nyugszik, a gazdasági kapcsolati háló csak követője a haderőnek, és hiába az intézményrendszer, mégis növekvő bizonytalanság és a növekvő kockázati tényezők jellemzik az emberiség életét.

Akár a vizek, a levegő vagy a föld szennyezettségét, akár a terrorizmust, a migrációt, a populizmus harmadik hullámának térnyerését nézzük, egyelöre megfelelö válaszok alig születtek a béke megőrzése és a polgárok szabadságjogainak tiszteletben tartása mellett. Simai úgy fogalmaz: „a történelem önálló fejezeteiként kellene megírni az ENSZ-nek a gazdasági és társadalmi 
fejlödésben, az emberi jogok kiterjesztésében és a nemzetközi jog új paragrafusainak megszületésében játszott szerepét, eredményeit, kudarcait és tévedéseit" [Simai, 2016:41]. A korábbi intézmények fenntartásánál és válaszkeresésénél nagyobb feladat vár a világ társadalmának szervezőire és katonai valamint gazdaságstratégiai tervezőire.

A szerző említi a tudásszakadék és a normatív szakadék kérdéskörét, amelynek enyhítésében leglényegesebb fórumként az ENSZ-et nevezi meg, mint a nemzetközi magatartási normákat meghatározó szervezetet, amely a nemzetközi rendszerbe vihető kiszámíthatóságot növeli. Amiért az új nemzedékek kamaszkori találkozása fontos a négy alaperénnyel, az éppen az, hogy az iskolás korban megtanult értékek egyfajta normaközösséget is feltételeznek majd. Az egyik legeredményesebb normaközösség-képző nemzetközi szervezetnek eddig az Európai Unió mutatkozott. Nagy kérdés, hogy a jelenlegi, külső és belső kihívásokkal küzdő EU milyen kiutakat talál, és milyen gazdasági, valamint társadalmi szerepet foglal el a multipolarizálódó világban. Itt is jelentős szerepe van az alapértékek újragondolásának, az emberekhez való közelebb hozásának és annak, hogy a tolerancia-kultúra valamint a békefenntartás fontossága a jelenkor fiataljainak is ugyanolyan értékes legyen, mint azoknak a generációknak, akik testközelből ismerték a háborús konfliktusokat. Emiatt hangsúlyos jelen dolgozatban az iskola szerepe, túl azon, hogy természetesen a globális intézményrendszerek, valamint a társadalomszervező rendszerekként is funkcionáló nemzetközi szervezetek is sokat tehetnek ezért.Az információs forradalomból következő technológiai robbanás törvényszerüen hozta magával - a gazdasági fejlödés mellett - az emberek nagyobb arányú vándorlását, valamint az egyes társadalmak keveredését. A világ demográfiai folyamatait tekintve a fejlődő világ népeinek lélekszáma az emberiség 90\%át fogja alkotni, és mivel a globális szegénységi szakadék jelentős társadalmi feszültségekkel jár, a XXI. századi kihívások között elsődleges helyen szerepel e feszültségek csökkentése. Fontossá válik a szakértői kormányzás, valamint a világ realista szemlélete, és az a típusú rugalmasság, amely képessé tesz egy nemzetgazdaságot, társadalmat és kormányokat arra, hogy gyorsan alkalmazkodjanak a változáshoz. A társadalmi kohézió, a közmegegyezés és a szakértelem szükséges minimumának biztositása éppen ugyanilyen fontosak lesznek az új évezred hajnalán elérhető sikerekhez vezető útig.,,Társadalmi meghatározottságú rendszer akkor kerülhet válságba, ha keretei között különbözö területek válságai halmozódnak, beépitett stabilizátorai, rendezö eröi nem vagy nem elég hatékonyan müködnek, és a politika rendelkezésre álló eszközei nem képesek visszaállitani a rendszer érdek- és értékviszonyait fenntartó müködőképességét." [Simai, 2016:69]

Jelentős társadalmi és politikai kihívás mind az Európai Közösség, a NATO, az ENSZ esetében, hogy müködésüket és eredményességüket nem pusztán azok kérdőjelezik meg, akik látszólag a globalizáció vesztesei, vagy akik tagjai sem voltak előbbi kettő közösségnek, de azok is, akik akár alapítóként vettek részt a szervezetek életében.

\section{A TERMÉSZET, A TÁRSAdAlom ÉS AZ EMBER}

Simai Mihály idézi Amartya Sen Nobel-díjas indiai közgazdász társadalmi fenntarthatóság-dimenzióit, mely tartalmazza az egyenlő társadalmi lehetőségeket, a sokrétűséget (diverzitást), a társadalmi kohéziót, az életminőséget (úgymint az alapvető szükségletek kielégitése, és mellette a foglalkoztatás és a biztonság), valamint a demokrácia és kormányzás minőségét - melynek legfontosabb eleme a felelősségre vonható kormányzati struktúra. Sen követelményeinek részeként a társadalom érettségét is elsők közt kell kezelni, mely szerint az egyének elfogadják felelösségüket abban, hogy országuk felemelkedhessen, növekedhessen, fenntartható legyen 
úgy környezeti, mint társadalmi értelemben: a társadalmi és az ökológiai rendszerek egymástól elválaszthatatlanok.

\section{EMBERI TÉNYEZŐK A XXI. SZÁZAD GLOBÁLIS TERMÉSZETI RENDSZERÉBEN}

A XX. század elejéhez mérten a világtermelés ötvenszeresére, az energiatermelés harmincszorosára emelkedett. A fotoszintézissel keletkező energia 40\%-át is az ember használja fel a Földön. $\mathrm{Az}$ „antropocén” környezeti rendszerében egyre nagyobb a kérdőjel: vajon mikor jön el egy olyan visszafordíthatatlan ökológiai katasztrófa, amelyen már a rendelkezésre álló erőforrásokkal nem tudunk segíteni. Kérdés, hogy nem következett-e már be egy ilyen, és a Föld nem a visszafordíthatatlan pusztulás felé halad-e.A könyv egészén végigvonul a részletes adatok bemutatása. Simai Mihály OECD-adatokat idéz 2011-ből, melyek szerint a tagországokban egy lakos évi átlagban 540 kilogramm szemetet termel, a tagországok pedig összesen közel 400 milliárd dollárt költenek hulladékgazdálkodásra ugyanennyi idő alatt. Az üvegházhatást fokozó gázok, a környezeti hatások tovagyürüző hatásai, a világgazdaság fejlődése miatt páratlan mértékben megnövekedett szén és olajtermelés mind megállíthatatlanul felfelé törő függvényekkel írhatók le.Noha a „Kyoto Protocol” által eredményezett buborékelvet sokan jónak minősítik, Simai Mihály megjegyzi: „A megállapodások és a vállalások teljesitése szinte valamennyi területen viszonylag lassú és egyenlötlen." [Simai, 2016:137] A globális felelősségvállalás akadozva oldódik meg, ráadásul a fejlett világ mind fogyasztói, mind termelői oldalon több szenet enged a légkörbe, mint a fejlődők. A szolidaritás és a fenntarthatóságért érzett felelősség javult ugyan, „bár továbbra is eltérő a különböző közösségek hozzáállása és globális ökológiai szolidaritásának mértéke” [Simai, 2016:139].

A fosszilis energiahordozók kitermelése, valamint a környezetterhelés egyéb formái mellett az általunk fogyasztott vízmennyiség is tetemes: az ENSZ becslése szerint 30 év múlva mintegy 14-17\%-kal több vízre lesz szükség a világ lakosságának élelemmel való ellátásához. A folyóvölgyek vízfelhasználásával kapcsolatos, jelentősen növekedett. A hulladék és mérgesgáz-képzés a termőtalaj romlásához is hozzájárul, a pusztulás az erdőket sem kíméli. „A felelősség azonban nem csak morális. A bioszféra gyakorlatilag felbecsülhetetlen értéket jelent az ember számára, és jövőjének is létfontosságú tartaléka." [Simai, 2016:162]

\section{ZöLD- VAGY ÖKOCIVILIZÁCIÓ, ZÖLD GAZDASÁG: IRREÁLIS KONCEPCIÓK VAGY A FEJLŐDÉS SZÜKSÉGSZERÜ KÖVETELMÉNYEI?}

Hogy a zöld- vagy ökocivilizáció és a zöld gazdaság irreális koncepció-e, jóval később derül csak ki. A gazdasági és társadalmi fejlődést elkerülhetetlen lesz abban mérni a jövőben, hogy hozzájárul-e a Föld környezeti értelemben vett fenntarthatóságához. „Az »ökocivilizáció« és a zöld gazdaság alapjainak lerakásában a 2015-ben elfogadott fenntartható fejlödési célok megvalósítás az egyik lényeges lépésnek ígérkezik." [Simai, 2016:167] Ehhez nem pusztán makroökonómiai elhatározások, de mikroökonómiai ösztönzők - adók, büntetések, szubvenciók, szabályozás - is szükségesek.

A fenntarthatóság-tudomány rendkívüli szerepet játszik a harmadik évezred hajnalán. Fontos témája, hogy a környezeti kormányzást összhangba tudja hozni a globális fenntarthatóság kihívásaival. Célja az emberek edukációja és felkészítése a XXI. századi kihívásokra, valamint arra, hogy a zöld gazdaságba való átmenet minél gördülékenyebb legyen számukra. „A tudomány és 
a politika közti megrongált hidak újjáépitése" sokak számára lehet irányadó az új stratégiák és fejlődési irányok megtalálásához.

\section{A VilÁggAZDASÁg SZERKEZETI RENDSZERE ÉS A GLOBÁLIS VÁLTOZÁSOK Fő IRÁNYAI}

Olyan célokat kell harmonizálni, mint a foglalkoztatás növelése, a szegénység csökkentése, a környezeti követelmények teljesülése, az életviszonyok javítása és a fogyasztók igényeinek kielégítése. Súlyos egyenlőtlenségek jellemzik a világgazdaságot, amelyek megtartása mellett aligha van továbblépés. A világtermelés fele a Föld 1,5\%-án történik, az euroatlanti szövetségi rendszer és Japán pedig a világ vagyonának kétharmadát magáénak tudja. A környezetterhelés is koncentráltabb. A „presztízsfogyasztás” vagy a „státuszfogyasztás”, a fogyasztóra nehezedő társadalmi nyomás kifejezetten káros - nem pusztán környezeti, de szociális értelemben is. A „környezeti lábnyom mutató”-ról alkotott képünk, a környezetvédelem fontosságába vetett hitünk sajnos a világtársadalom jelentős hányadának fogyasztási szokásain nem változtatott.

\section{AZ AGRÁRSZEKTOR GLOBÁLIS SZEREPE ÉS A GLOBÁLIS VÁLTOZÁSOK Fő IRÁNYAI}

Az ivóvízkészletek 70\%-át itt használják fel, a metán- és nitrogén-dioxid kibocsátás 47 és 58\%-a itt keletkezik. A termelési folyamatok alapvetó átalakítása elengedhetetlen. Az elmúlt fél évszázadban másfél hektárról alig több mint fél hektárra zsugorodott az egy före jutó termőterület a világon, és a termőtalaj minősége romlott. A technológiai fejlődés következtében az agrárszektor is globalizálódott, és nőtt a nemzetközi szabályozás rendszere, azon belül is a környezetvédelemre vonatkozó előírásoké. Az élelmiszerbiztonság szempontjából is vizsgálni kell az agráriumot. Az 1996-os élelmezési világcsúcs azt mondta ki, hogy azt nevezzük élelmiszerbiztonságnak, hogy mindenki mindig hozzájuthat az aktív életének fenntartásához szükséges, biztos, tápláló élelemhez. Ettől azonban messze vagyunk. 2,5-3 milliárd ember szegénynek tekinthető, súlyos nyomorban él az egyharmaduk.

Az új szemlélet szerint az organikus fejlődés elősegítése az irányadó, ahol a tudomány és a technika legújabb vívmányai segítenek abban, hogy korszerü és kevésbé környezetterhelő legyen a termelés.

\section{A FENNTARTHATó IPARI FEJLŐDÉS FELTÉTELEI, AZ ANYAGFORRADALOM ÉS AZ ENERGIASZEKTOR}

Nagy felelőssége van a szektor strukturális és stratégiai átalakulásának abban, hogy végül elérhető legyen a fenntartható fejlődés. Megindult, és javuló tendenciát mutat a felhasznált víz visszaforgatása, valamint a káros anyagok kiszürése az elhasznált vízből. „A kitermeló ágazat szerepe a fenntartható fejlődésben ellentmondásos." [Simai, 2016: 225] A demográfiai folyamatok, valamint az ásványkincsek mennyiségének végessége okozza ezt a helyzetet. Megkülönböztetünk „puha” és „kemény” fenntarthatóságot. Előbbi szerint a kitermelés okozta környezeti károk rehabilitálhatók, és újra a társadalom szolgálatába állíthatók. Utóbbi gondolat azt fogalmazza meg, hogy a természeti tőke kimerítése esetén nem lehet majd helyettesíteni. Az atomenergiát egyelöre sokan nem tartják helyettesíthetőnek, ugyanakkor van egy másik, jelentős csoport, amely szeretné „kiradírozni” az atomkorszakot az emberiség életéből. [Simai, 2016: 249]A jelenlegi célok közt 
szerepel továbbá „az olcsóbb, biztonságosabb és környezeti szempontból is megfelelö villamos áram termelése". [Simai, 2016: 251] Ami reményre adhat okot: a középtávú energiafelhasználás növekedési ütemét alacsonyabbra becsülik, mint a várható gazdasági növekedési ütemét.

\section{8. „A NEGYEDIK IPARI FORRADALOM”, FENNTARTHATÓ GYÁRIPARI FEJLŐDÉS VAGY ÚJRAIPAROSÍTÁS? STRATÉGIÁK ÉS SZEREPLÖK AZ IPARPOLITIKÁBAN}

A világgazdaság zöldebbé tétele stratégiailag is fontos cél, és nem mindegy, hogy az új technológiai helyzetben, amelynek keretében a $\mathrm{K}+\mathrm{F}$ legnagyobb hányada változatlanul a gyáriparra koncentrálódik, merre megy a globális intézményrendszer, hogyan tud szabályozni a környezeti fenntarthatóság érdekében. Az UNIDO, az ENSZ Iparfejlesztési Szervezete definiálja is, hogy zöldnek tekinthető az a tevékenység, amely nem szennyezi a környezetet, a természetet, és nem károsítja az emberek egészségét, nem vezet a természeti erőforrások kiaknázásának állandó növekedéséhez.A vállalati kultúra átalakulása a gazdaság szerkezeti átalakulása miatt is fontos szerepet játszik majd. A vegyipar és a hadiipar nagyarányú környezetterhelése vonatkozásában az ENSZ környezetvédelmi világprogramja megfogalmaz irányelveket, azért, hogy a vegyiparban is megteremthetők legyenek a fenntartható fejlődés előfeltételei. A világ vegyianyag-felhasználásában a fejlődő világ kétharmad részt vállal. Itt is van szerepe az UNEP-nek és az UNIDO-nak, e hulladékok esetében is szeretnék előremozdítani a fenntarthatóságot: az újrahasznosítás, a reciklálás és a megsemmisités fázisát is a fenntarthatóság kell, hogy áthassa csakúgy, mint a termelés, a tervezés és a felhasználás fázisait.A földi- és a légiközlekedés volumenének megnövekedése mögött lakossági és szállítmányozási okokat is találunk. A nemzetközi mobilitás igénye feltartóztathatatlanul növekszik a XXI. században, így annak fékezése aligha lehet cél. Sokkal fontosabbak az olyan technológiai áttörések, amelyek kímélik a környezetet. Az „ökomenedzsmentet” tekintve a transznacionális vállalatoknak különös felelösségük van, de az egyes nemzeti kormányok és nemzetközi intézmények is tehetnek azért, hogy a gazdaság és a társadalom „zöldebbe”” váljon. Sajnos itt is megjelenik a potyautas- vagy a tisztességtelen magatartás.

\section{9. „A GAZDA NÉLKÜLI VILÁG MENEDZSEREI” (A FENNTARTHATÓ FEJLŐDÉS JöVőJE ÉS A GLOBÁLIS KORMÁNYZÁs)}

Kérdéses, hogy a világ hogyan tudja kezelni a közös cselekvést kikényszerítő kihívások teremtette konfliktusokat. Itt is rendkívül fontos szerepe van az együttmüködési készségnek, az egymás iránti szolidaritásnak és a folytonos megoldáskeresésnek. A Harry Potter társadalmi hatásait feldolgozó tanulmány éppen ezeket a készségeket erősítette a kutatásban részt vevő fiatalokban, ami reménykeltő.A „governance” fogalma többet jelent a szabályozásnál, de kevesebbet a kormányzásnál. A világkormány nem léte azt eredményezi, hogy a globális kormányzás a világkereskedelem és a világtársadalom életében valamilyen alrendszer szabályozására és irányítására tesz lépéseket, mint a nemzetközi pénzügyek, a fenntartható fejlödés vagy az egészségügy. Erre közös menedzsmentet is felállít. Világkormány híján a megoldáskeresés és az együttmüködési készség nagyban függ a részt vevő államok belpolitikai viszonyaitól.A globális kormányzás sajátossága, hogy olyan kihívásokra keresi a választ, melyek kialakulásáért a részt vevő államok túlnyomó része felelős, és felismerték a közös felelősséget az e kihívásokra keresendő válaszokban. A nemzeti kormányok, az NGO-k és a kormányközi szervezetek azok, amelyeket az ENSZ is elismer mint aktorokat, és ezek összefogásából és közös cselekvéséből 
épülhet fel egy olyan fenntartható világ, amely az emberiség és a bolygó megmaradásáért sikeresen küzdhet meg.Minden eszmerendszer keretében megjelent a környezetvédelem, politikai pártok és civil mozgalmak széles köre foglalkozik a kérdéssel. A zöld pártok aránya és népszerüsége nagymértékben nőtt az elmúlt évtizedekben. A világvallások, a kormányok, valamint a nemzetközi szervezetek viszonyulása a fenntartható fejlődéshez kulcskérdés. A Dalai Láma, a Szentszék vagy a Zsidó Világkongresszus szava meghatározó ezekben a kérdésekben. Simai Mihály Ferenc pápát idézi a könyv 312. oldalán: „Az emberi környezet és a természeti környezet együtt megy tönkre, és nem tudjuk megfelelöen kezelni a környezet pusztulását, ha nem szentelünk figyelmet azoknak az okoknak, amelyek az emberi és társadalmi hanyatlással állnak összefüggésben. Tény, hogy a környezet és a társadalom pusztulása különösen is érinti a bolygónkon élö leggyengébbek életét." [Simai, 2016:321] A pápa úgy látja: egymással legalább olyan rosszul bánunk, mint a Földdel, közös intézményrendszert és közös cselekvést sürget. A hátrányos megkülönböztetéstől és emberi méltóságtól szenvedő társadalmi csoportokra is tekintettel kell lennünk. Simai átfogó képet ad a világvallások az ember és természet viszonyát leíró gondolatairól, szót ejt a „Világ Vallásainak Parlamentjê”-ről.

\section{A HARMADIK ÉVEZRED NYITÁNYA: ZAVAROK, VÁLSÁGOK, ÚTKERESÉS}

Pozitív, hogy a „környezeti analfabetizmus” korszaka lezárulni látszik, és egyre elterjedtebb a nézet, miszerint globálisan kell gondolkodnunk, de lokálisan cselekednünk. Ha a cél közös, akkor már „,csak” eszközrendszert kell találni. Sokan javasolták a közjavak árának megfizettetését, vagy mutatók kidolgozását a környezetszennyezésre nézve. A regionális szervezetek és nemzetközi szervezetek szerepe megnövekedett a fenntartható fejlődésért tett erőfeszítéseket illetően. Sokat segíthet ebben az ENSZ „A kivánatos jövő" (The Future we Want) címen megszületett programja, amely a fenntarthatóságot, a zöld fejlődés előmozdítását, és a szegénység felszámolásáért tett erőfeszítéseket integrálja.A környezeti célok mellé felzárkóznak az ENSZ által meghatározott célok közt a békés és inkluzív társadalmak, valamint a globális partnerségi program müködöképessége. A tanulmány és a Harry Potter könyvek kapcsán említett szeretet valahol itt kapcsolódik össze legszorosabban Simai Mihály könyvével. Nem a világvallások és azok fenntartható fejlődésért vállalt felelőssége miatt, hanem azért, mert talán kimondható, hogy a dolgozat első fejezetében tárgyalt „egyéni szintü” szeretet társadalmi megjelenése az egymás iránti tisztelet kultúrája. A XXI. századi kihívások minden eddiginél erősebben kérdezik a jelenkor emberét, hogy kész-e valóban tisztelettel viszonyulni embertársaihoz és a Földhöz. Amennyiben a válasz igen, úgy bízhatunk abban, hogy a globális kormányzás és a nemzetközi intézményrendszerek képesek lesznek a Föld lehetö legtöbb polgárával együttmüködve tenni azért, hogy ne pusztán a környezetünk, de a társadalmi békénk is fenntartható maradjon.

\section{ÖSSZEFOGLALÁs}

Simai Mihály „A harmadik évezred nyitánya” címü, 2016-ban megjelent könyvét azért tartottam fontosnak a „Harry Potter legnagyobb varázslata: csökkenti az elöitéleteket” című tanulmánnyal közösen elemezni, mert úgy látom, hogy a Földnek és az emberiségnek mind környezeti, mind társadalmi értelemben fenntarthatóvá kell válnia. Míg a zöld mozgalmak, NGO-k, zöld pártok, „zöld kormányzás” a tudományra alapoz, azt is állítja, hogy „a politika és a tudomány közti, megrongált hidak helyreállitásán" keresztül létrejöhet egy új szemléletű gazdaság, amely megfelelő 
ösztönzőkkel a vállalati szektorban, valamint makroökonómiai eszközökkel vissza tudja fordítani a környezetünkben okozott károkat. Persze társadalmi kapcsolatainkban is sok a teendő.

A tanulmány rávilágít a XXI. század egyik fontos kihívására: a régi világrend felbomlása gazdasági, társadalmi és környezeti értelemben a régi értékektől való elfordulást hozta el sokak számára. Bár a tolerancia-kultúrában egyre kevesebben hisznek, erre szükség van ahhoz, hogy a társadalomban újraépülhessen az egymás iránti tisztelet.

Az olasz szerzők tanulmányukban azt bizonyították, hogy pusztán a Harry Potterben megjelenő karakterek és sorsuk azt okozta az olvasókban, hogy elfogadóbbá váltak azokkal szemben, akiket a társadalom hagyományosan kirekeszt, és hajlamosabbak fellépni a kirekesztő gondolatokkal szemben. Ennek nyomán, jelen dolgozatban azt állítom, hogy az iskola az az intézmény, amely képes lehet átadni az ókori görög filozófia alaperényeit a diákoknak és elvezetni a társadalmat egy olyan helyzetig, ahol törésvonalak nélkül készek közösen dolgozni egy fenntartható jövőért. Elengedhetetlen ugyanis, hogy a társadalmi árkok betemetése is bekövetkezzen a XXI. században, mert a IV. ipari forradalomra, a formációelméleti váltásra, a környezeti kihívásokra adandó válaszok megtalálásához a lehető legtöbbekre van szükség. Erre társadalmi hidegháborúban nem kerülhet sor.

A dolgozat azt is állítja ezeken felül, hogy a társadalmi kohézióhoz elengedhetetlen folyamatok indultak el a kutatás résztvevőiben, így feltételezhető, hogy ezt lehet reprodukálni az iskolákban. E feladatot éppoly fontos lesz ellátni a fenntarthatóság érdekében, mint azt, hogy a jelenkor társadalmai megtanuljanak kisebb ökológiai lábnyomot hagyni maguk után.

A kerek születésnap ünneplése pedig talán azt a megjegyzést is megengedi, hogy a fenti célok eléréséhez fontos a globális kormányzás, fontos a világtársadalom összetartozásának érzete, közös értékeinek és érdekeinek újradefiniálása, egy új korszellem, amely képes ezek megfelelő közvetítésére, és stabil intézményrendszerek felépítése a célok elérésének érdekében. De talán még fontosabb - és e gondolat egyúttal leírja a generációk egymás iránti felelősségvállalásának kötelezettségét is -, hogy a fenti folyamatok elindításához és véghezviteléhez nem pusztán Harry Potterekre, de Dumledore-okra is nagyobb szükség van, mint valaha.

\section{Felhasznált irodalom}

Arisztotelész (1992): Poétika. 2. kiad. Ford. Sarkady János. Budapest, Kossuth Könyvkiadó.

(Azóta megjelent újabb fordításban is a mü: Arisztotelész 1997. Poétika. Ford. Ritoók Zsigmond. H. n., PannonKlett Kiadó)

Dardot, P. - Laval, C. (2013): A globálrezon, a neoliberalizmus múltja és jelene, EgyKettő Kiadó, Budapest

Erhardt, L. (1957/1993): Jólétet mindenkinek. Konrad Adenauer Alapítvány Budapesti Képviselete, Budapest

Gervai P. - Trautmann L. (2013): A neoliberális "kapitalizmus" fogalom megszünése (The disappearance of the term "neoliberal capitalism"). Köz-gazdaság, 8(1): 35-52.

Hume, D. (1748/1995): Tanulmány az emberi értelemről. https://www.scribd.com/ document/237239070/Hume-Tanulmany-Az-Emberi-Ertelemr\%C5\%911. Lekérdezve: 2020. február 20.

Kant, I. (1996): A gyakorlati ész kritikája. Osiris, Budapest

Röpke, W. (2000): Emberséges társadalom - Emberséges gazdasá, Aula Kiadó, Budapest

Rowling, J. K. (2019): Harry Potter I-VII. Animus Kiadó, Budapest 
Russ, R. (2014): How Adam Smith Can Change your life: an Unexpected guide to Human nature and Happiness. Penguin Book

Simai M. (2016): A harmadik évezred nyitánya - a zöld fejlődés esélyei és a globális kockázatok, Corvina Kiadó, Budapest

Smith, A. (1982): The Theory of Moral Sentiments. Szerk: Raphael, D. D. and MacFie, A. L. Indianapolis, Liberty classics

Smith, A. (1959): A nemzetek gazdagsága. E gazdagság természetének és okainak vizsgálata. Akadémiai Kiadó, Budapest

Tóth Cs. (2016): A sci-fi politológiája, Athenaeum Kiadó, Budapest

Vezzali, L., Stathi, S. Giovannini, D. , Cappoza, D., Triffiletti, E. (2015): „The greatest magic of Harry Potter: Reducing prejudice" Journal of Applied Social Psychology 45: 105-121 